\title{
POTENSI BAHAYA BAGI KESELAMATAN PENGUNJUNG DI KAWASAN WISATA PANTAI PANGANDARAN KABUPATEN PANGANDARAN JAWA BARAT
}

\author{
Hazard Potentials on Visitors Safety in Pangandaran Beach Tourism Destination, \\ Pangandaran District, West Java
}

\author{
EKS Harini Muntasib ${ }^{\mathrm{a}}$, Melly Maria Ulfah ${ }^{\mathrm{a}}$, Agustinus Samosir ${ }^{\mathrm{b}}$, Resti Meilani ${ }^{\mathrm{a}}$ \\ ${ }^{a}$ Departemen Konservasi Sumberdaya Hutan dan Ekowisata, Fakultas Kehutanan, Institut Pertanian Bogor, \\ Kampus IPB Darmaga, Bogor 16680 - harinimuntasib@yahoo.com \\ ${ }^{b}$ Departemen Manajemen Sumberdaya Perikanan, Fakultas Perikanan dan Ilmu Kelautan, Institut Pertanian Bogor, \\ Kampus IPB Darmaga, Bogor 16680
}

\begin{abstract}
Pangandaran Beach Tourism Area is one of leading tourism areas in West Java. During certain period of time, hazard has often cause accidents toward visitors in the area. Therefore, there is a need to identify physical and biological hazards which threaten visitors' safety in order to develop visitor safety management. Research was carried out in June - July 2011, and an update was conducted in January - February 2017, which covered three locations, i.e. Pantai Barat, Pantai Timur, and Pantai Pasir Putih. Field observation, interview with visitors, community and lifeguard, and literature review were employed in data collection. A hundred respondents for each visitor and community was selected using convenient sampling method. The result found rip current, plunging wave, tsunami, earthquake, wave, and tide as physical hazard, while jellyfish, sea snake, sea urchin, lionfish, and stone fish as biological hazard found in the sea, and long-tailed macaque as terrestrial biological hazard. Rip current possessed substantial risk that had to be avoided through the establishment of swimming prohibition area. Visitor's safety management technique option for rip current hazard involved a socialization toward visitors about self-rescue technique in case they are swept by rip current.
\end{abstract}

Keywords: Hazard management, Pangandaran Beach, risk, safety, visitors

(Diterima: 08-06-2017; Disetujui: 28-09-2017)

\section{Pendahuluan}

\subsection{Latar Belakang}

Pangandaran adalah salah satu tempat yang menjadi obyek wisata unggulan di Provinsi Jawa Barat dan terletak di Desa Pananjung Kecamatan Pangandaran dengan jarak $\pm 92 \mathrm{~km}$ arah selatan Kota Ciamis. Sampai tahun 2011, kawasan ini masih termasuk dalam Kabupaten Ciamis, dan sejak tahun 2012 termasuk ke dalam Kabupaten Pangandaran, yang merupakan pemekaran dari Kabupaten Ciamis.

Kawasan ini memiliki berbagai daya tarik wisata meliputi keindahan pantai, serta taman laut yang memungkinkan pengunjung untuk melakukan berbagai kegiatan wisata seperti berenang, berperahu pesiar, memancing dan kegiatan wisata lainya. Sebagai obyek wisata unggulan provinsi Jawa Barat, Pangandaran banyak dikunjungi oleh wisatawan dalam negeri maupun luar negeri dengan jumlah wisatawan yang berkunjung setiap tahun rata-rata 450.300 orang dari dalam negeri (wisatawan nusantara) dan sekitar 4.100 wisatawan mancanegara (UPTD Obyek Wisata Ciamis 2011). Pada tahun 2016, wisatawan mancanegara sebesar 3.804, sedangkan wisatawan nusantara sebesar 1.399.156 (Disbudpar Kabupaten Pangandaran, 2017). Wisatawan yang berkunjung ke Obyek Wisata Pangandaran sejauh ini didominasi oleh wisnus atau wisatawan domestik. Puncak kunjungan wisata di Pangandaran biasanya terjadi pada musim libur sekolah, hari raya Lebaran, libur Natal, dan Tahun Baru, dan kecenderungan ini masih terjadi sampai tahun 2017.

Kawasan Wisata Pangandaran menjadi tempat menarik bagi pengunjung karena keindahan pantainya, namun arus dan ombak Pantai Pangandaran pada periode tertentu dapat menjadi potensi bahaya bagi para pengunjung. Selama musim libur lebaran tahun 2007, tercatat 102 wisatawan terbawa ombak pantai tersebut (Republika, 2007), dan pada libur pergantian tahun 2010 tercatat 10 wisatawan mengalami kecelakaan yang sama di kawasan wisata ini (Dhani, 2011). Pada tahun baru 2016 tercatat 50 kecelakaan, sedangkan pada tahun baru 2017 tercatat 20 kecelakaan dan satu orang meninggal, sehingga dapat dikatakan sudah menurun.

Peristiwa kecelakaan maupun bencana alam di Kawasan Wisata Pangandaran dapat terjadi sewaktuwaktu dan mengancam keselamatan pengunjung. Hal ini merupakan salah satu bahaya yang terjadi di kawasan wisata ini. Menurut Grift (2006), bahaya adalah suatu kondisi yang timbul secara alamiah maupun karena perbuatan manusia, yang berpotensi menimbulkan kerusakan atau kehilangan jiwa manusia. Potensi bahaya dapat mengancam keselamatan dan keamanan pengunjung, aspek yang sangat penting dalam kegiatan 
wisata. Calon pengunjung memiliki banyak pilihan untuk berkunjung ke suatu tempat wisata. Kondisi tempat wisata yang aman dapat mempengaruhi jumlah kunjungan wisata.

Pengunjung yang merasa aman saat berkunjung akan lebih banyak meluangkan waktunya serta memiliki kecenderungan untuk melakukan kunjungan kembali (Prasetiyo, 2006). Sebaliknya, pengunjung yang memiliki pengalaman negatif akan memiliki kepuasan yang lebih rendah dan kemungkinan berkunjung kembali yang juga lebih rendah (Howard, 2009).

Manajemen bahaya dibutuhkan pada semua kawasan wisata, termasuk Kawasan Wisata Pantai Pangandaran, untuk memastikan keselamatan dan keamanan pengunjung, dan lebih lanjut memastikan keberlanjutan wisata di suatu kawasan. Manajemen bahaya merupakan suatu kegiatan dengan maksud tertentu yang dilaksanakan oleh pengelola untuk mengurangi kemungkinan terluka, kematian, atau kehilangan hak milik yang terjadi pada partisipan dari sebab yang telah diketahui atau yang masih diperkirakan, baik bahaya alami maupun buatan manusia yang terdapat di suatu kawasan wisata (Jubenville et al., 1987). Untuk dapat mengembangkan manajemen bahaya, perlu dilakukan identifikasi potensi bahaya bagi keselamatan pengunjung di Kawasan Wisata Pantai Pangandaran sebagai masukan dan rekomendasi bagi pengelola dan pengunjung untuk dapat melakukan tindakan pencegahan, serta mengembangkan manajemen bahaya yang sesuai.

\subsection{Tujuan}

Penelitian ditujukan untuk mengidentifikasi potensi bahaya bagi keselamatan pengunjung dalam kaitannya dengan kegiatan wisata di Kawasan Wisata Pantai Pangandaran, serta memberikan rekomendasi bagi pengelola dalam manajemen bahaya yang akan di lakukan.

\section{Metode Penelitian}

Kegiatan penelitian ini dilaksanakan pada bulan Juni - Juli 2011 dan ulangan untuk pembaharuan data dilakukan pada bulan Januari - Februari 2017. Lokasi penelitian meliputi Pantai Barat, Pantai Timur, dan Pantai Pasir Puth di Kawasan Obyek Wisata Pantai Pangandaran Kabupaten Pangandaran, Jawa Barat.

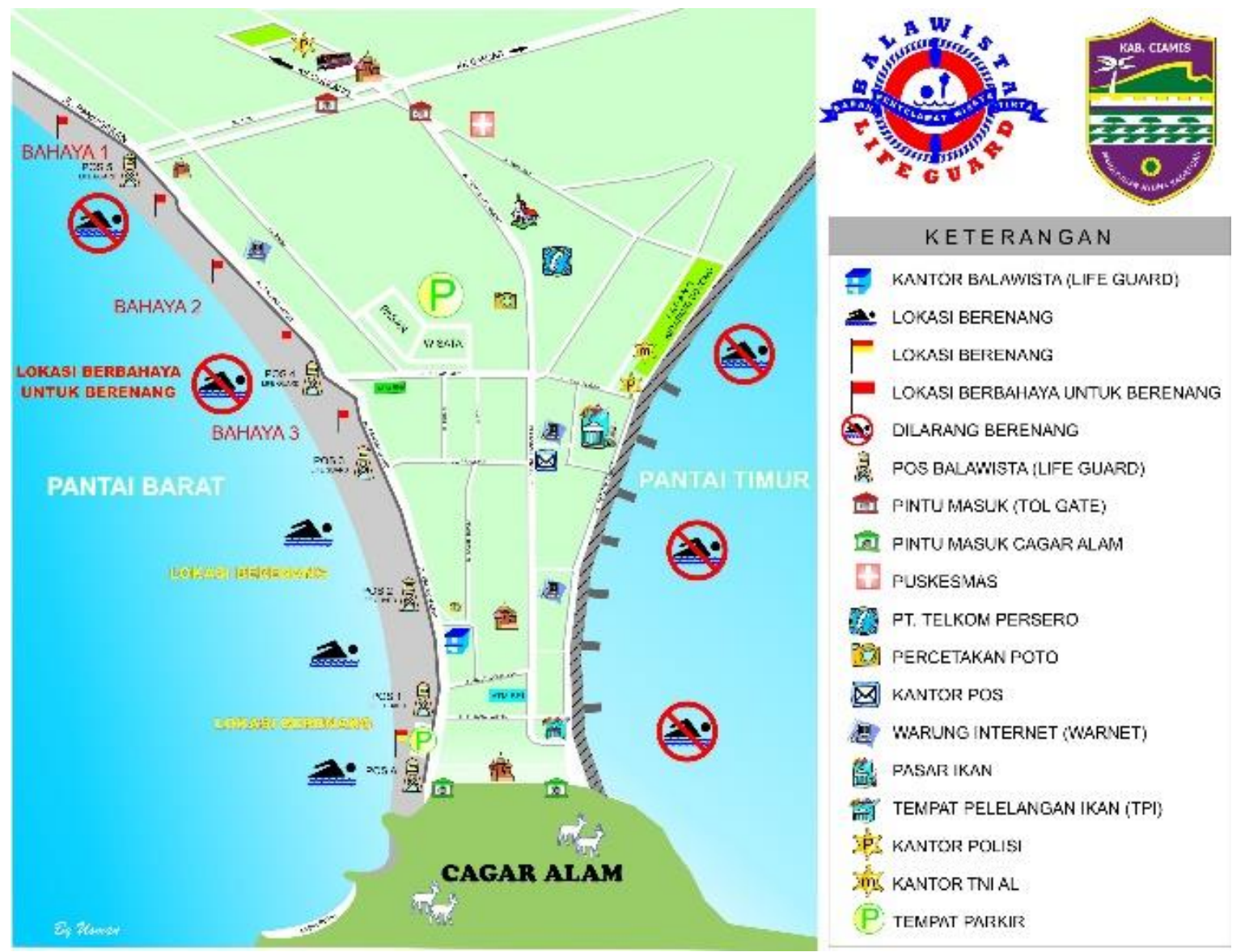

Sumber: Dinas Kebudayaan dan Pariwisata Kabupaten Ciamis, 2010.

Gambar 1. Lokasi penelitian. 


\subsection{Data yang dikumpulkan}

Data dikumpulkan melalui observasi lapang dan pengambilan sampel serta dokumentasi potensi bahaya fisik dan biologi, serta wawancara dengan pengunjung, pengelola, dan masyarakat pada tahun 2011. Pembaharuan data dilakukan melalui wawancara kepada pengelola dan Badan Penyelamat Wisata Tirta (Balawista) pada tahun 2017. Wawancara kepada pengelola dilakukan kepada key informant dari masing-masing instansi terkait. Wawancara dilakukan secara semi terstruktur kepada responden pengunjung dan masyarakat, dengan metode penentuan responden berturut-turut adalah purposive sampling dan convenient sampling. Jumlah responden pengunjung dan masyarakat, masing-masing 100 responden, ditentukan menggunakan rumus slovin (Sevilla et al., 1993), sebagai berikut:

$$
n=\frac{N}{1+N e^{2}}
$$

dengan $\mathrm{n}=$ ukuran sampel, $\mathrm{N}=$ ukuran populasi, dan $e$ = nilai kritis (batas ketelitian) yang diinginkan (persen kelonggaran ketidaktelitian karena kesalahan pengambilan sampel populasi).

Studi pustaka dan dokumen dilakukan untuk memperoleh berbagai data pendukung terkait bahaya di Pantai Pangandaran. Pustaka yang digunakan berupa buku, dokumen data instansi terkait (Balawisata, Angkatan Laut, Pemerintah Daerah, Dinas Pariwisata Kabupaten Ciamis, Dinas Pariwisata Kabupaten Pangandaran, Dinas Kelautan dan Perikanan Kabupaten Ciamis, Puskesmas, BKSDA, serta Badan Meteorologi, Klimatologi dan Geofisika/BMKG), media cetak dan media elektronik.

Data yang dikumpulkan berupa data potensi, bentuk dan variabel bahaya yang ada di Kawasan Wisata Pantai Pangandaran. Data Fisik meliputi data fisik pantai (materi pembentuk pantai (pasir, batu), topografi (landai, curam), data air (ombak tukik, pasang surut, arus rip, tinggi ombak), angin (kecepatan, potensi bahaya), kejadian gempa dan tsunami serta resiko bahaya gempa dan tsunami, serta organisme pantai yang berpotensi bahaya.

Selain itu, dikumpulkan pula data mengenai bencana atau kecelakaan yang pernah terjadi, penyebab terjadinya kecelakaan ataupun bencana, waktu kejadian, tempat kejadian, dan jumlah korban, fenomena alam yang berpeluang mengancam keselamatan pengunjung di tempat rawan bencana atau kecelakaan, kerugian yang disebabkan oleh bahaya, serta kegiatan penanggulangan dan pengelolaan terhadap potensi bahaya yang telah dan mungkin akan terjadi oleh pelaku wisata. Persepsi, pendapat dan harapan setiap kelompok masyarakat pelaku wisata terhadap pelayanan keselamatan pengunjung juga dikumpulkan.

\subsection{Analisis Data}

Penilaian dilakukan terhadap resiko potensi bahaya faktor fisik dan biologi. Tiap-tiap potensi bahaya yang diperoleh diberi bobot peluang (likelihood; Tabel 1) dan tingkat keparahan (severity; Tabel 2), mengacu pada panduan UNEP (2008).

Tabel 1. Pembobotan peluang terjadinya bahaya

\begin{tabular}{lcl}
\hline \multicolumn{1}{c}{ Peluang } & Nilai & \multicolumn{1}{c}{ Keterangan } \\
\hline Sangat sering & 5 & Terjadi pada hampir setiap keadaan \\
Sering & 4 & Terjadi pada sebagian besar waktu \\
Cukup sering & 3 & $\begin{array}{l}\text { Sering terjadi pada kondisi tertentu } \\
\text { Kadang-ka- }\end{array}$ \\
dang & 2 & $\begin{array}{l}\text { Terkadang terjadi pada kondisi ter- } \\
\text { tentu }\end{array}$ \\
Jarang & 1 & Hanya terjadi pada kondisi ekstrem \\
\hline Sumber: UNEP (2008) &
\end{tabular}

Tabel 2. Tingkat keparahan potensi bahaya

\begin{tabular}{|c|c|c|}
\hline Keparahan & Nilai & Keterangan \\
\hline Sangat parah & 16 & $\begin{array}{l}\text { Gangguan pasti menimbulkan ke- } \\
\text { matian }\end{array}$ \\
\hline Parah & 8 & $\begin{array}{l}\text { Gangguan kadang-kadang men- } \\
\text { imbulkan kematian }\end{array}$ \\
\hline Cukup parah & 4 & $\begin{array}{l}\text { Gangguan menyebabkan luka } \\
\text { serius (permanen) }\end{array}$ \\
\hline Agak parah & 2 & $\begin{array}{l}\text { Gangguan kecil/ menyebabkan luka } \\
\text { ringan }\end{array}$ \\
\hline Tidak parah & 1 & Tidak ada gangguan berarti \\
\hline
\end{tabular}
Sumber: UNEP (2008)

Kriteria peluang dan keparahan didapat dari wawancara kepada masing-masing 100 responden pengunjung dan 100 responden masyarakat. Kriteria peluang dan keparahan yang dipilih adalah hasil dari responden terbanyak yang menjawab masing-masing potensi bahaya. Pemaparan potensi bahaya yang paling menimbulkan resiko kemudian dihitung menurut fungsi dari kemungkinan peluang (likelihood) dan keparahan (severity), dengan rumus berikut:

Resiko $($ risk $)=$ Peluang $($ likelihood $) \times$ Keparahan $($ severity)

Tingkat resiko potensi bahaya diperoleh dengan memetakan hasil perhitungan ke dalam matriks level resiko (Tabel 3). Opsi manajemen bahaya ditentukan dengan mengacu pada evaluasi resiko UNEP (2008; Gambar 2).

Tabel 3 Matriks level resiko

\begin{tabular}{|c|c|c|c|c|}
\hline \multirow{2}{*}{\multicolumn{2}{|c|}{$\begin{array}{c}\text { Resiko = Peluang } x \\
\text { Keparahan }\end{array}$}} & \multicolumn{3}{|c|}{ Keparahan } \\
\hline & & Rendah & Sedang & Tinggi \\
\hline \multirow{3}{*}{ 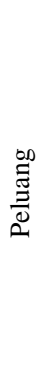 } & $\begin{array}{l}\text { Rendah } \\
\text { Nilai } \leq 16\end{array}$ & $\begin{array}{c}\text { Tingkat } \\
\text { bahaya } \\
\text { sangat ren- } \\
\text { dah }\end{array}$ & $\begin{array}{l}\text { Tingkat } \\
\text { bahaya } \\
\text { rendah }\end{array}$ & $\begin{array}{c}\text { Tingkat } \\
\text { bahaya se- } \\
\text { dang }\end{array}$ \\
\hline & $\begin{array}{l}\text { Sedang } \\
16<x \leq 51\end{array}$ & $\begin{array}{l}\text { Tingkat } \\
\text { bahaya } \\
\text { rendah }\end{array}$ & $\begin{array}{l}\text { Tingkat } \\
\text { bahaya se- } \\
\text { dang }\end{array}$ & $\begin{array}{l}\text { Tingkat } \\
\text { bahaya } \\
\text { tinggi }\end{array}$ \\
\hline & $\begin{array}{l}\text { Tinggi } \\
51<x \leq 70\end{array}$ & $\begin{array}{l}\text { Tingkat } \\
\text { bahaya se- } \\
\text { dang }\end{array}$ & $\begin{array}{c}\text { Tingkat } \\
\text { bahaya } \\
\text { tinggi }\end{array}$ & $\begin{array}{l}\text { Tingkat } \\
\text { bahaya } \\
\text { sangat } \\
\text { tinggi }\end{array}$ \\
\hline
\end{tabular}




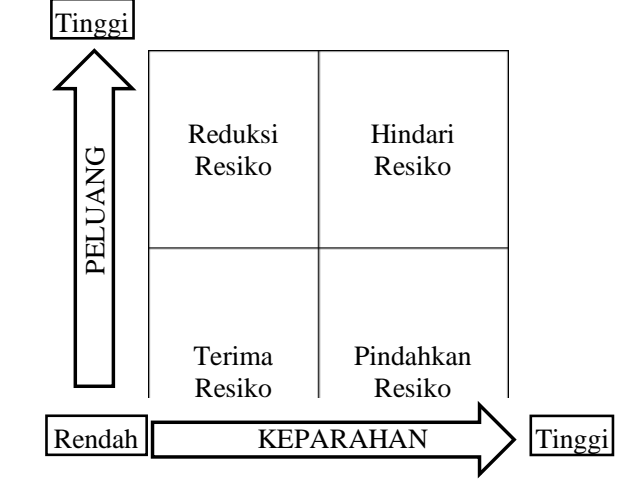

Sumber: UNEP 2008

Gambar 2. Opsi manajemen pengurangan resiko potensi bahaya.

\section{Hasil dan Pembahasan}

\subsection{Jenis Kegiatan Wisata di Kawasan Pantai Pangandaran.}

Kegiatan wisata pantai yang biasa dilakukan pengunjung di Kawasan Wisata Pantai Pangandaran berupa berenang, berperahu pesiar, bermain pasir, menikmati keindahan pantai seperti melihat pemandangan sunset dan sunrise, snorkling serta kegiatan wahana wisata air seperti banana boat, donat, dan water head. Selain kegiatan tersebut terdapat beberapa kegiatan yang disenangi oleh sebagian pengunjung yaitu kegiatan yang merupakan minat khusus seperti memancing, menyelam (diving), berselancar (surfing). Berdasarkan hasil wawancara diperoleh hasil bahwa kegiatan yang paling banyak disukai oleh pengunjung adalah kegiatan berenang, yaitu sebanyak $52 \%$; berperahu pesiar dan snorkling sebanyak $9 \%$, sebanyak $8 \%$ menyukai banana boat, dan sebanyak $6 \%$ menyukai kegiatan bermain pasir, menikmati pemandangan pantai dan menyelam sebanyak $5 \%$, surfing sebanyak $4 \%$ dan memancing sebanyak $2 \%$.

Kegiatan wisata di kawasan ini dilakukan di tiga lokasi yaitu Pantai Barat yang difokuskan untuk kegiatan berenang, Pantai Timur untuk kegiatan wahana air, serta Pasir putih untuk kegiatan snorkling, diving, serta berselancar. Ketiga lokasi tersebut memiliki keunikan tersendiri, yaitu Pantai Barat merupakan pantai yang landai dan aman untuk kegiatan berenang dan merupakan pantai dengan substrat pasir, Pantai timur yang merupakan pantai untuk konsentrasi wahana air dan merupakan pantai yang dalam sehingga tidak diperuntukan kegiatan berenang. Pantai Pasir putih yang memiliki pantai berpasir putih berasal dari pecahanpecahan karang. Pantai ini merupakan bagian dari
Cagar Alam Laut Pananjung Pangandaran yang memiliki berbagai jenis biota laut seperti ikan, dan terumbu karang, sehingga memberikan pemandangan indah dan menjadi daya tarik utama bagi kegiatan wisata di Pangandaran. Pengelola dari Balai Konservasi Sumberdaya Alam Resort Pangandaran juga telah menetapkan sejumlah peraturan bagi pengunjung yang tujuannya agar pengunjung tetap menjaga kelestarian berbagai biota laut serta terumbu karang yang terdapat di Kawasan tersebut.

\subsection{Potensi bahaya fisik}

Potensi bahaya fisik yang dapat ditemukan di Kawasan Wisata Pantai Pangandaran terdiri dari arus rip, ombak tukik, gempa bumi, tsunami, gelombang, dan pasang surut. Pengetahuan pengunjung mengenai potensi bahaya fisik masih terbatas. Hanya 20\% pengunjung yang menyebutkan arus rip, 23\% menyebutkan tsunami, $15 \%$ ombak tukik, dan $9 \%$ gempa bumi sebagai potensi bahaya fisik di Pangandaran. Masyarakat menunjukkan pengetahuan yang lebih beragam: $15 \%$ menyebutkan arus rip, $15 \%$ tsunami, $12 \%$ ombak tukik, $12 \%$ gempa bumi, $2 \%$ gelombang besar, dan $1 \%$ pasang surut.

Tsunami sangat jarang terjadi. Gelombang besar biasanya dibentuk oleh angin yang kencang. Angin kencang yang terjadi di Daerah Pangandaran biasanya terjadi pada bulan September sampai Nopember (DKP Kabupaten Ciamis, 2011). Potensi bahaya fisik yang seringkali menyebabkan kerugian jiwa adalah arus rip dan ombak tukik, yang terjadi di Pantai Barat Pangandaran.

\subsubsection{Potensi bahaya arus rip (Rip current)}

Arus rip biasanya muncul di Pantai Barat Pangandaran. Pos jaga Balawista Pangandaran ditempatkan pada 5 titik di pantai ini untuk memudahkan pengawasan terhadap aktivitas pengunjung, yaitu Pos 1 (bagian selatan) sampai Pos 5 (bagian utara pantai). Kemunculan arus rip terbanyak yaitu pada lokasi Pos 3 sebanyak 63 kali, pada lokasi Pos 4 sebanyak 32 kali, dan pada lokasi pos 5 sebanyak 28 kali (Gambar 3). Menurut Setiawan (2010), Lokasi Pos 3, Pos 4, dan Pos 5 Pantai Barat Pangandaran merupakan pantai dengan morfologi pantai beach cup dan morfologi dasar laut berupa punggungan dan lembah yang merupakan bentuk morfologi yang paling berpengaruh dalam pembentukan proses arus rip. Hingga awal tahun 2017, lokasi tersebut masih menjadi lokasi kemunculan arus rip terbanyak. 


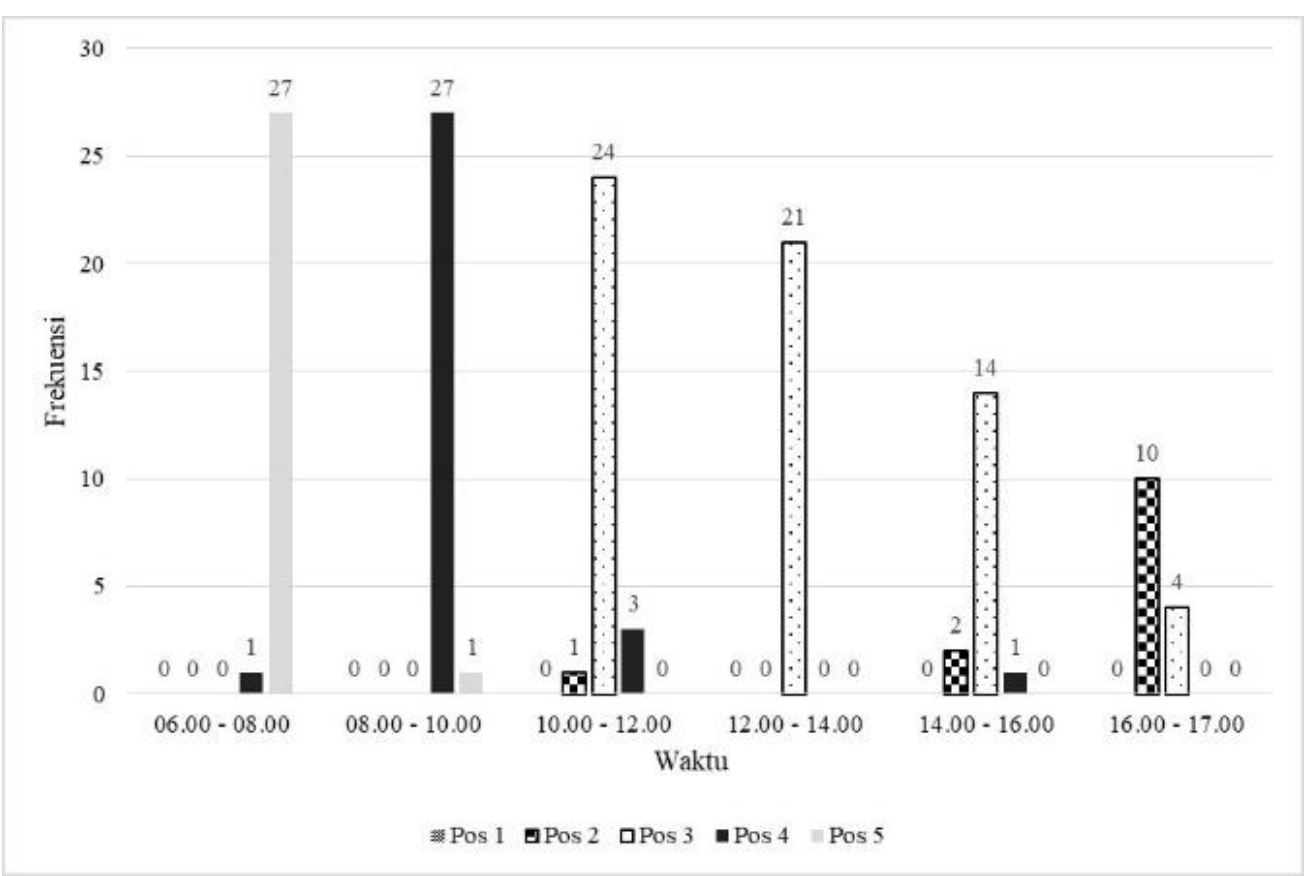

Sumber: Balawista Pangandaran 2011

Gambar 3. Frekuensi kemunculan arus rip berdasarkan waktu dan lokasi di Pantai Barat Pangandaran pada Bulan Juni 2011.

Arus rip merupakan arus yang berkembang di dekat pantai yang bergerak dari pantai ke arah laut (Hutabarat dan Evans, 1984), yang menjadi menjadi penyebab orang yang berenang di pantai terseret ke laut (Setyawan et al., 2010). Pantai dengan morfologi beach cup serta morfologi dasar laut yang berupa punggungan dan lembah, merupakan bentuk morfologi yang berpengaruh penting pada pembentukan arus rip karena setelah gelombang pecah, air yang naik ke pantai akan terbelah oleh tanjung (horn) dari morfologi beach cup, kemudian massa air yang terbelah itu masuk ke dalam "teluk" di kedua sisinya dan bertemu di bagian tengah dengan air dari sisi yang lain dari beach cup dan kemudian bersama-sama kembali ke laut sebagai arus rip (Komar, 1976; Dyer, 1986 diacu dalam Setyawan et al., 2010).

Frekuensi kemunculan arus rip dalam sehari akan meninggi ketika air laut pasang dan mencapai puncaknya ketika pasang tertinggi, kemudian frekuensinya kembali menurun ketika air laut bergerak surut dan mencapai frekuensi terendah ketika air laut surut terendah (Setyawan et al., 2010). Kenampakan secara visual arus rip dapat dilihat dengan adanya perbedaan kenampakan riak-riak di permukaan laut yang memanjang bergerak ke laut, serta adanya jalur buih yang memanjang ke arah laut. Kehadiran arus rip ini juga dapat dilihat dari adanya celah pada jalur gelombang pecah di sepanjang pantai.

Pos 4 - Pos 5 pada Kawasan Pantai Barat Pangandaran terindikasi memiliki arus Rip permanen yang tetap ada, dan Pos 3 - Pos 4 memiliki frekuensi kemunculan arus rip yang cukup tinggi, sehingga ditetapkan sebagai segmen zona bahaya oleh petugas penjaga pantai Pangandaran yang disebut Badan Penyelamat Wisata Tirta (BALAWISTA). Pos 1 - Pos 3 sebelum menara pengamatan merupakan zona berenang. Pembagian zona arus ini ditentukan oleh pengelola berdasarkan frekuensi kemunculan arus rip yang cenderung tinggi pada zona bahaya, meskipun arus rip terkadang timbul pada zona berenang, sesuai dengan faktor-faktor oceanografi yang berpengaruh, seperti pasang surut, kondisi arus dan gelombang. Untuk mengantisipasi kejadian kecelakaan akibat arus rip, petugas memasang bendera berwarna merah sebagai tanda peringatan pada setiap lokasi yang terdapat arus rip sesuai waktu dan lokasi timbulnya arus rip.

Selain menetapkan zona bahaya dan zona berenang, petugas juga menetapkan jadwal berenang yaitu mulai pukul 06.00 WIB -17.00 WIB untuk mengantisipasi kecelakaan. Namun demikian, masih ada pengunjung yang mengabaikan tanda peringatan yang dipasang dan melakukan aktivitas berenang di Zona Bahaya, dan ada pula pengunjung yang melakukan aktivitas berenang di luar jam yang sudah ditetapkan, sehingga tidak terpantau oleh Petugas Balawista. Hal serupa ditemukan oleh Gstaettner et al. (2017) pada penelitiannya yang menunjukkan adanya pengunjung yang mengabaikan peringatan dan tetap melakukan kegiatan yang beresiko. Lebih lanjut Gstaettner et al. (2017) menjelaskan bahwa hal tersebut berkaitan dengan persepsi pengunjung yang memandang manfaat dari kegiatan berbahaya tersebut lebih besar daripada resiko yang mungkin terjadi padanya dan bahwa dirinya terlepas dari kemungkinan terjadinya bahaya. Namun pada kenyataannya di Pangandaran, hal tersebut seringkali menimbulkan korban. Pada tahun 2010, korban yang mengalami kecelakaan laut di Pos 4 akibat arus rip sebanyak 89 orang, dan pada bulan Januari - Juni 2011 sebanyak 28 orang. Korban yang mengalami kecelakaan laut akibat arus rip di Pos 5 sebanyak 8 orang pada tahun 2010, dan sebanyak 1 orang pada bulan Januari - Juni 2011.

Sebagian besar pengunjung $(77 \%)$ dan masyarakat $(63 \%)$ menyatakan bahwa arus rip merupakan bahaya 
dengan kriteria bahaya yang parah, sehingga diberi bobot 8 . Berdasarkan peluang terjadinya, sebagian besar pengunjung $(51 \%)$ dan masyarakat $(48 \%)$ menyatakan peluangnya sering, sehingga diberi bobot 4 . Skor resiko arus rip sebesar 32 tergolong ke dalam kriteria tingkat resiko bahaya besar (substantial risk). Namun demikian, pengunjung masih cukup banyak (50\%) yang tidak mengetahui adanya zona bahaya di lokasi Pantai Barat Pangandaran ini. Ketidak tahuan tersebut menyebabkan pengunjung berenang pada zona bahaya arus rip. Perilaku pengunjung yang tetap berenang pada zona bahaya tersebut dapat memengaruhi pengunjung lain yang tidak berpengalaman untuk mengikutinya. Melihat pengunjung lain melakukan suatu hal dapat menyebabkan seorang pengunjung mengira hal tersebut aman untuk dilakukan tanpa mempertimbangkan keterampilan dan pengalamannya sendiri (Gstaettner $e t$ al., 2017).

Pengetahuan pengunjung mengenai zona arus rip pada lokasi berenang di Pantai Barat merupakan faktor yang penting untuk mengantisipasi berbagai resiko yang dapat ditimbulkan dari potensi bahaya arus rip. Dengan demikian, masih diperlukan peningkatan sosialisasi dan pemberian informasi mengenai zona bahaya dan zona aman pada lokasi berenang di Pantai Barat tersebut.

\subsubsection{Potensi bahaya ombak tukik (Plunging wave)}

Ombak tukik (Plunging wave) di Pantai Barat Pangandaran selama bulan Juni 2011 diperoleh bahwa selama pengamatan telah terjadi ombak tukik (plunging wave) sebanyak 51 kali. Ombak tersebut merupakan ombak dengan kekuatan yang besar dan curam dan dapat mendorong para perenang sampai ke dasar laut. Menurut Balawista Pangandaran, ombak tukik menjadi pemicu terjadinya kecelakaan laut seperti cedera patah tulang pada pengunjung yang melakukan aktivitas berenang dan penyebab perahu pesiar terbalik.

Frekuensi terjadinya ombak tukik berdasarkan waktu selama bulan Juni 2011 di Pantai Barat Pangandaran, paling sering terjadi pada pukul 12.00 WIB 17.00 WIB sebanyak $10 \mathrm{kali}$, sedangkan pada pukul 06.00 WIB-12.00 WIB frekuensi kemunculannya lebih rendah (Gambar 3). Frekuensi kemunculan ombak tukik dengan frekuensi tertinggi pada pukul 12.00 WIB-17.00 WIB dikarenakan pada waktu tersebut kondisi air laut di Pantai Barat dalam keadaan surut. Surf Life Saving Australia (2005) menyatakan bahwa ombak tukik biasanya terjadi pada saat air surut, dan terdapat tumpukan pasir yang dangkal. Menurut petugas Balawista Pangandaran, ombak tukik juga biasanya terjadi pada saat cuaca ekstrim, sehingga pada Januari - Februari 2017 dengan kondisi cuaca biasa tidak terjadi ombak tukik.

Kejadian ombak tukik selama Januari - Juni 2011 telah menimbulkan 13 korban dari perahu pesiar yang terbalik karena tertimpa ombak tukik, dengan 11 korban diantaranya mengalami luka berat. Luka berat yang dialami korban yang terbanyak adalah patah tulang. Penilaian skor resiko ombak tukik sebesar 8 pada matriks level resiko digolongkan pada kriteria resiko 20 moderate risk. Meskipun tingkat keparahannya cukup parah, namun ombak tukik tidak terlalu sering terjadi.

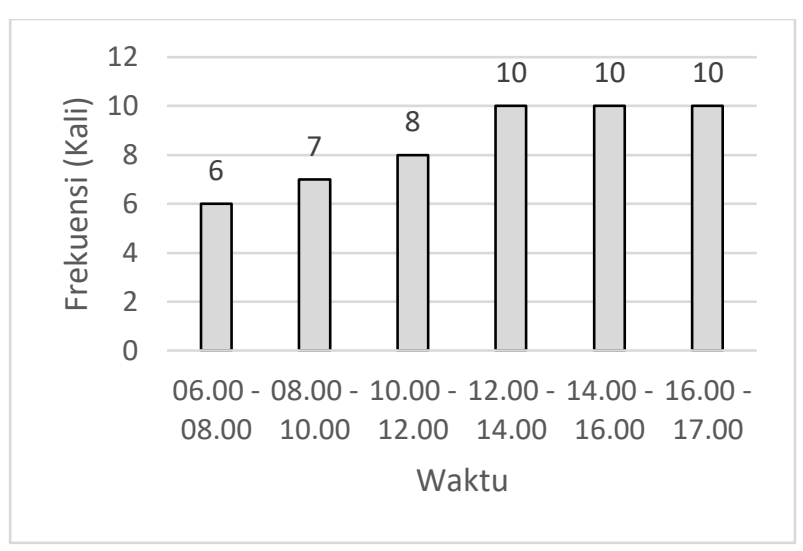

Gambar 3. Frekuensi terjadinya ombak tukik di Pantai Barat Pangandaran selama bulan juni 2011.

\subsubsection{Potensi bahaya gempa bumi dan tsunami}

Secara geologis Indonesia merupakan wilayah tektonik aktif yang merupakan lokasi tumbukan beberapa lempeng tektonik, yaitu Indo-Australia, Eurasia, Pasifik, Carolina dan beberapa lempeng kecil lainya. Kondisi geomorfologi kawasan sepanjang Pesisir Pangandaran merupakan suatu dataran rendah yang sangat luas dan didominasi oleh pantai berpasir (DKP Kabupaten Ciamis, 2011). Aspek morfologi bentuk lahan pantai yang berupa dataran merupakan bentuk lahan yang rentan oleh tsunami secara keseluruhan, serta pantai dengan relief datar merupakan bentuk lahan yang paling rentan untuk terkena tsunami dibandingkan dengan bentuk lahan yang berbukit atau bergunung meskipun terletak di pinggir pantai (Djunire, 2009).

Berdasarkan data dari BMKG (2011) Pangandaran telah mengalami 4 kali gempa besar $(2006$ - 2010) dengan pusat gempa di dasar laut. Berdasarkan skala intensitasnya (MMI), gempa tahun 2006-2010, termasuk skala intensitas I-IV. Gempa di dasar laut dapat memicu terjadinya tsunami (Sugito, 2008), terutama gempa dengan skala intensitas IV (BMKG, 2011) yang terjadi di Pangandaran pada 2006. Tsunami yang terjadi dibangkitkan oleh deformasi vertikal dasar laut yang diakibatkan oleh gempa subduksi yang memiliki momen seismik yang besar dan dangkal. Patahan yang terjadi di wilayah Pangandaran termasuk ke dalam patahan komplek (complex fault). Tsunami tersebut merupakan tsunami earthquake karena memiliki durasi yang lama, kecepatan patahan yang lambat, dan getaran. Tsunami yang terjadi di Pangandaran mengakibatkan 184 orang meninggal dunia serta menyebabkan kerusakan rumah dan hotel. Sejak tsunami terakhir di tahun 2006 tersebut, sampai 2017 tidak terjadi tsunami, meskipun gempa masih terjadi. Baik tsunami maupun gempa bumi tergolong pada kriteria resiko sedang (moderate risk), yang memiliki tingkat keparahan sangat parah, namun peluang terjadi sangat jarang. 


\subsection{Potensi bahaya biologi}

Potensi bahaya biologis yang dapat ditemukan di Pantai Pangandaran berupa ubur-ubur, ular laut, bulu babi, karang, ikan lepu ayam, ikan lepu batu dan monyet ekor panjang (Macaca fascicularis).

Pengunjung menyebutkan potensi bahaya biologi berupa ubur-ubur (9.8\%), monyet ekor panjang (16\%), ular laut (1\%), bulu babi $(0.2 \%)$, dan karang $(6 \%)$. Masyarakat memberikan dua tambahan potensi bahaya yang tidak diketahui oleh pengunjung, dan menyebutkan bahwa potensi bahaya biologi terdiri dari monyet ekor panjang (14\%), ubur-ubur (12\%), karang (3\%), ular laut (13\%), bulu babi (7\%), ikan lepu ayam (2\%) dan ikan lepu batu (2\%). Ikan lepu ayam dan lepu batu tidak pernah dijumpai memberikan resiko bagi pengunjung, karena itu pengunjung tidak menyebutkannya.

\subsubsection{Potensi bahaya ubur-ubur (Jelly fish).}

Ubur-ubur banyak ditemukan di sekitar Pantai Timur Kawasan Wisata Pantai Pangandaran yang merupakan tempat penangkapan ikan. Menurut Heriawan (1994), ubur-ubur adalah biota pemakan zooplankton, sama halnya dengan ikan, sehingga pada Pantai Timur ini keberadaan ubur-ubur cenderung lebih tinggi dibandingkan dengan Pantai Barat dan Pasir Putih. Selama penelitian yaitu Pada Bulan Juni yang merupakan awal musim kemarau, kelimpahan ubur-ubur cenderung tinggi di Pantai Timur Pangandaran. Intensitas cahaya, yang dibutuhkan untuk proses fotosintesis fitoplankton, di awal musim kemarau cenderung tinggi, sehingga ketersediaan fitoplankton juga tinggi. Karena ketersediaan fitoplankton tinggi, maka ketersediaan zooplankton juga tinggi, sehingga keberadaan ubur-ubur melimpah (Moller (1987) diacu dalam Heriawan (1994)).

Ada 3 jenis ubur-ubur yang ditemukan di Pangandaran, yaitu ubur-ubur berwarna putih bening (Aurelia aurita), ubur-ubur berwarna cokelat kekuningan ( $C y a-$ nea sp.), dan ubur-ubur biru. Ubur-ubur digolongkan sebagai potensi bahaya karena berpotensi menyengat yang menyebabkan gatal-gatal, demam, sampai dapat menyerang jantung dan mematikan korban yang tersengat (Barnes (1987) diacu dalam Tillah (2006)). Menurut Tillah (2006) dan Heriawan (1994), jenis ubur-ubur A. aurita dan Cyanea sp. termasuk ubur-ubur dengan resiko bahaya ringan sampai sedang, karena dapat menyebabkan gatal-gatal sampai demam, sedangkan ubur-ubur biru memiliki daya sengat yang lebih tinggi, karena racun yang terdapat dalam uburubur tersebut dapat menyerang jantung dan mematikan. Menurut Wahyuningsih (2010), semakin mencolok warna ubur-ubur, maka semakin tinggi tingkat racunnya.

Pantai Timur merupakan lokasi wisata wahana air seperti banana boat, jetski, dan water head. Selama penelitian cukup banyak pengunjung yang menikmati wahana air banana boat menjadi korban sengatan uburubur. Hal itu terjadi saat pengemudi banana boat melakukan atraksi menjatuhkan penumpangnya di tengah laut, sehingga pengunjung yang terjatuh mungkin tersengat ubur-ubur. Meskipun jenis ubur-ubur tertentu dapat menyebabkan kematian, sampai saat ini tidak ada korban sengatan ubur-ubur di Pantai Timur Pangandaran yang meninggal. Pengunjung yang mengalami korban sengatan ubur-ubur di Pantai Timur Pangandaran biasanya ditangani oleh pemilik banana boat dengan mengoleskan mentimun atau sabun krim pada bagian yang disengat. Menurut Tillah (2006), untuk pertolongan pertama pada manusia yang tersengat ubur-ubur, terutama ubur-ubur Cyanea sp., yaitu dengan menyiramkan air panas pada bagian yang terkena sengatan mulai dari suhu $40^{\circ} \mathrm{C}$ yang dapat mengurangi gejala awal, seperti rasa terbakar, tanda merah atau gatal-gatal.

Pengunjung (76\%) dan masyarakat (93\%) paling banyak menjawab potensi bahaya ubur-ubur sebagai kriteria bahaya yang agak parah, sehingga diberi bobot 2. Peluang terjadinya sengatan ubur-ubur dipandang sebagian besar pengunjung dan masyarakat (masing-masing 74\%) jarang terjadi, sehingga diberi bobot 1 . Skor tingkat resiko sebesar 2, sehingga potensi bahaya ubur-ubur termasuk kategori rendah/tolerable risk.

\subsubsection{Potensi bahaya ular laut (sea snake)}

Ular laut berwarna dominan kuning dan bercak hitam dengan panjang sekitar $60 \mathrm{~cm}$ ditemukan bersembunyi pada terumbu karang, saat air laut dalam keadaan surut di sekitar Pasir Putih. Hal ini sesuai dengan penelitian Aziz (1976) yang menyatakan bahwa ular laut biasanya ditemukan saat air laut dalam keadaan surut dan sering ditemukan berada diantara celah-celah batu atau diantara karang mati.

Ular laut termasuk dalam filum Chordata, kelas reptilia, dan ordo Squamata. Hewan ini menyesuaikan diri untuk berenang dengan bentuk ekornya yang pipih seperti dayung. Biota laut ini hampir semuanya termasuk hewan berbisa yang sangat beracun dan dilengkapi dengan gigi taring (Romimohtarto dan Juwana, 2001), sehingga memiliki potensi bahaya bagi pengunjung.

Ular laut yang ditemui di Pantai Pasir putih ini menyerupai jenis Cerberus rhynchops, yang dapat mencapai panjang lebih dari 1.5 meter. Ular laut jenis tersebut yang berukuran kecil jika dipegang biasanya jarang menggigit namun tetap merupakan ular berbisa. Jenis ular tersebut termasuk kelompok vivipar dan biasanya terdapat di rawa mangrove, pantai bercadas dan pantai dengan terumbu karang (Romimohtarto dan Juwana, 2001).

Komposisi kimia bisa ular pada umumnya merupakan suatu kompleks protein yang bersifat netral atau sedikit asam dan bersifat toksin yang disebut erabu toksin, dengan daya racun atau virulensi yang relatif lebih kuat dibandingkan ular yang hidup di darat (Countville (1970) diacu dalam Aziz (1976)). Lebih lanjut Aziz (1976) menjelaskan bahwa jika seseorang digigit ular laut, mula-mula tidak merasa sakit pada bagian luka gigitan dan pada umumnya tidak mengeluarkan darah yang mungkin disebabkan taring bisa dari 
ular laut relatif lebih kecil, tetapi cairan bisa yang masuk ke tubuh segera bergabung dengan plasma darah dan terbawa oleh aliran darah ke otak, menghambat fungsi pusat pernafasan yang terdapat di otak dan merusak sel-sel darah merah, sehingga selanjutnya korban merasa pusing dan mengalami kejang, kehilangan kesadaran, dan bahkan kematian dalam beberapa jam atau hari setelah peristiwa penggigitan bila tidak segera mendapat pertolongan, tergantung daya tahan tubuh, jenis ular laut dan usia hewan tersebut. Ular muda (juvenile) memiliki daya racun yang cenderung relatif lebih kuat dibandingkan dengan ular dewasa (Aziz, 1976).

Selama ini belum terdata adanya pengunjung yang meninggal karena digigit ular laut di kawasan pasir putih, namun karena biota laut tersebut hidup di sekitar karang di kawasan tersebut, pengelola perlu melakukan antisipasi bahaya akibat ular laut terhadap pengunjung yang datang ke kawasan pasir putih. Pengunjung maupun masyarakat menyebutkan bahwa tingkat keparahan bahaya ular laut termasuk dalam kategori agak parah, sehingga diberi bobot 2 . Tingkat peluang terjadinya kecelakaan oleh ular laut jarang terjadi, sehingga diberi bobot 1 . Dengan demikian, tingkat resiko sebesar 2, yang tergolong rendah/tolerable risk.

\subsubsection{Potensi bahaya bulu babi (Sea urchin)}

Bulu babi merupakan salah satu potensi bahaya biologi yang banyak ditemukan di Pantai Pasir Putih, diam bersembunyi di dalam karang. Hal tersebut dilakukan bulu babi untuk menghindari intensitas cahaya yang kuat (Fuji et al. (1985) diacu dalam Kasim (1999)). Fauna ini umumnya menghuni ekosistem terumbu karang dan padang lamun serta menyukai substrat yang agak keras terutama substrat di padang lamun campuran yang terdiri dari pasir serta pecahan karang (Aziz (1994) diacu dalam Dobo (2009)).

Bentuk tubuh hewan laut ini bulat tanpa lengan dan dipenuhi duri-duri yang menutup seluruh tubuh. Bulu babi ini umumnya berwarna hitam dengan duri-duri yang panjang dan beracun, sehingga hewan laut ini memiliki potensi bahaya (Gitrix et al., 2005). Hewan laut ini tergolong dalam filum Echinodermata serta kelas Echinoidea. Jenis bulu babi yang terdapat di perairan Pangandaran yaitu jenis Diadema sitosum (DKP Kabupaten Ciamis, 2011).

Hewan yang memiliki nama internasional sea urchin atau edible sea urchin ini tidak mempunyai lengan, tubuhnya umumnya berbentuk seperti bola dengan cangkang yang keras berkapur dan dipenuhi dengan duri-duri sangat panjang (dapat mencapai $>10 \mathrm{~cm}$ ), lancip seperti jarum dan sangat rapuh yang terletak berderet dalam garis-garis membujur dan dapat digerakgerakkan (Nontji (2005) diacu dalam Romimohtarto dan Juwana (1985)). Penyelam yang tidak menggunakan alas kaki mudah sekali tertusuk durinya sehingga akan sedikit merasakan demam karena bisa pada duri tersebut, racunnya sendiri dapat dinetralisir dengan amoniak, atau perlakuan asam ringan (jeruk lemon atau cuka). Resiko bahaya dari biota laut tersebut yaitu ujung duri akan masuk ke dalam telapak kaki telanjang, terlarut dalam darah, dan menimbulkan rasa sakit dan bengkak (Romimohtarto dan Juwana, 2001).

Pasir putih merupakan lokasi aktivitas pengunjung, sehingga keberadaan bulu babi di area tersebut memberikan potensi bahaya bagi pengunjung, terutama pada pengunjung yang tidak memahami potensi bahaya biota laut tersebut. Pengunjung dan masyarakat menilai tingkat keparahan bahaya bulu babi agak parah, sehingga diberi bobot 2. Tingkat peluang terjadinya kecelakaan akibat bulu babi dinilai jarang terjadi, sehingga diberi bobot 1 . Skor tingkat resiko sebesar 2, menempatkan resiko bahaya bulu babi sebagai resiko yang dapat ditoleransi karena rendah.

\subsubsection{Potensi bahaya karang}

Keberadaan karang yang keras atau masif dan karang mati di Kawasan Wisata Pantai Pangandaran, terutama di area Pantai Pasir Putih, memberikan potensi bahaya bagi pengunjung, yaitu menyebabkan luka gores. Terumbu karang di kawasan ini didominasi oleh karang-karang masif yang merupakan karang berbentuk padat dan keras serta karang mati.

DKP Kabupaten Ciamis (2011) menyebutkan bahwa karang yang terdapat di Pangandaran yaitu sekitar Pasir putih didominasi oleh karang mati mencapai $61 \%$ kemudian berturut-turut diikuti oleh alga makro (16\%), karang non Acropora (9\%), pecahan karang (8\%), sponge (4\%), Acropora $(0,6 \%)$, dan karang lunak $(0,6 \%)$. Jenis karang yang terdapat di Kawasan Wisata Pantai Pangandaran adalah Goniastrea retiformis, Goniastrea favulus, Goniastrea aspera, Goniastrea pectinata, Platygira pini, Platygira lamellina, Montastrea curta, Monstastrea annuligera, Monstastrea magnistellata, Leptastrea transversa, Cyphastrea serailia, $C y$ phastrea chalcidium, Echinopora lameliosa, Echinopora gemmacea, dan Echinopora hirsutissima (DKP Kabupaten Ciamis, 2011).

Terumbu karang di Pangandaran terdapat pada kawasan dengan Pantai Pasir Putih yang memiliki material dasar berupa karang berpasir (Winni, 2011). Pada kawasan ini biasanya pengunjung melakukan aktivitas wisata seperti berenang, snorkling, surfing, dan diving. Pengunjung yang kurang berhati-hati, misalnya berjalan pada karang-karang tanpa alas kaki, atau melakukan snorkling tanpa menggunakan pelindung kaki, dapat terpapar bahaya dari karang-karang tersebut.

Tingkat keparahan bahaya karang dinilai agak parah oleh pengunjung dan masyarakat, sehingga diberi bobot 2. Pengunjung dan masyarakat menilai peluang terjadinya bahaya akibat karang ini jarang terjadi, sehingga diberi bobot 1 . Skor resiko bahaya karang sebesar 2, sehingga termasuk kategori resiko yang dapat ditolerir (tolerable risk).

\subsubsection{Potensi bahaya monyet ekor panjang}

Monyet ekor panjang (Macaca fascicularis) merupakan salah satu potensi bahaya darat di Kawasan Pantai Pangandaran, terutama pada kawasan Pasir Putih yang 
berdekatan dengan Cagar Alam Pananjung Pangandaran, habitat monyet ekor panjang ini. Pada lokasi ini banyak pengunjung yang melakukan aktivitas wisata, dan terkadang monyet ekor panjang ini menunjukkan perilaku agresif terhadap pengunjung. Monyet ekor panjang di kawasan ini sudah mengalami perubahan perilaku karena terlalu sering berinteraksi dengan pengunjung, serta kebiasaan pengunjung memberikan makanan pada M. fascicularis (Hendratmoko, 2009).

Gangguan yang ditimbulkan monyet ekor panjang terhadap pengunjung berupa perilaku menggigit, mencakar, dan mengambil barang bawaan pengunjung seperti makanan, kantong plastik, kamera, dan lain-lain. Menurut (Anonim, 2010) diacu dalam Widiatuty et al. (2010), banyak pengunjung di kawasan tersebut yang mengeluh atau menghindar dari monyet ekor panjang, karena apabila terlalu dekat atau terdapat kelalaian sedikit saja, mengakibatkan kerugian seperti hilangnya barang serta tergigitnya pengunjung. Resiko potensi bahaya yang lebih parah dan memerlukan langkah antisipasi dari pengelola yaitu gigitan atau cakaran monyet ekor panjang yang dikhawatirkan dapat menyebabkan infeksi virus rabies ke dalam tubuh korban.

Rabies merupakan penyakit infeksi viral yang bersifat akut pada susunan syaraf oleh virus rabies dari genus Lyssavirus, famili Rhabdoviridae yanng secara klinis ditandai dengan kelumpuhan progresif dan berakhir dengan kematian (Prihatiana, 2010). Menurut Fenner (1993) diacu dalam Prihatiana (2010), inang dari virus rabies ialah semua hewan berdarah panas dan manusia. Di Indonesia hewan yang pernah dilaporkan terserang rabies selain anjing, adalah kucing, dan monyet. Monyet merupakan salah satu dari tiga spesies yang paling potensial sebagai penyebar penyakit rabies dengan prevalensi $3 \%$. Kasus gigitan monyet telah banyak dilaporkan di Indonesia sehingga dapat dinyatakan bahwa monyet ialah hewan yang mengancam dalam perananya sebagai penyebar penyakit rabies (Hardjosworo (1977) diacu dalam Prihatiana (2010)). Selain virus rabies, resiko bahaya interaksi antara pengunjung denga monyet ekor panjang yaitu virus Avian influenza. Menurut (Putra, 2008) diacu dalam Prihatiana (2010), terdapat monyet ekor panjang yang pernah terpapar oleh virus avian influenza tipe H5.

Monyet ekor panjang di TWA dan CA Pananjung Pangandaran belum pernah disuntik vaksin. Hal ini perlu mendapat perhatian khusus dari pengelola mengingat adanya interaksi yang cukup tinggi antara pengunjung dengan monyet ekor panjang. Upaya yang telah dilakukan pengelola untuk mengurangi resiko bahaya monyet ekor panjang adalah mengingatkan pengunjung akan bahaya yang mungkin ditimbulkan, menghimbau pengunjung untuk tidak membawa barang jinjingan seperti kantong plastik, dan melarang pengunjung memberi makan monyet ekor panjang.

Responden pengunjung (65\%) dan masyarakat (39\%) paling banyak menjawab potensi bahaya monyet ekor panjang (M. fascicularis) sebagai kriteria bahaya yang agak parah, sehingga diberi bobot 2. Pengunjung (17\%) dan masyarakat $(71 \%)$ menyatakan bahwa peluang terjadinya kecelakaan akibat monyet ejor panjang kadang (agak sering) terjadi, sehingga diberi bobot 2. Penilaian skor resiko sebesar 4 pada matriks level resiko digolongkan pada kriteria resiko tolerable risk, dengan tingkat resiko rendah dan masih dapat ditoleransi.

\subsection{Manajemen Pengurangan Resiko Bahaya}

Manajemen pengurangan resiko bahaya untuk tujuan wisata pantai dilakukan dengan mengevaluasi setiap resiko bahaya yang terdapat pada kawasan, kemudian membuat rekomendasi pilihan (opsi) manajemen yang harus dilakukan. Langkah manajemen ini merupakan strategi mengatasi bahaya yang terdapat pada suatu kawasan wisata. Terdapat empat pilihan pengurangan resiko yang dapat dipertimbangkan, disesuaikan dengan tingkat keparahan, frekuensi terjadinya, serta tingkat resiko dari suatu jenis bahaya. Pilihan manajemen tersebut yaitu menerima resiko yang dapat ditoleransi ( $a c$ cepting tolerable risk), menghindari resiko (avoiding risk), mengurangi resiko (reducing risk), dan mentransfer resiko (transferring risk).

Arus rip, dengan resiko substansial karena tingkat keparahan dan frekuensi yang tinggi, dapat dikurangi resiko bahayanya dengan cara menghindari resiko (avoiding risk). Hal ini dilakukan dengan menetapkan larangan berenang pada lokasi Pos 3 sampai Pos 5 yang memiliki arus rip permanen. Namun demikian, penetapan larangan berenang ini saja tidak lah memadai. Pendidikan akan bahaya arus rip bagi pengunjung dan cara menyelamatkan diri dari arus rip perlu diberikan melalui berbagai cara, seperti himbauan dan peringatan melalui pengeras suara, pemasangan tanda bahaya pada lokasi bahaya arus rip, pengembangan papan-papan interpretasi, dan berbagai media interpretasi lainnya, ataupun menerapkan roving interpretation di area pantai dengan bahaya arus rip. Paparan terhadap media interpretasi mengenai arus rip diharapkan akan dapat meningkatkan pengetahuan pengunjung dan memengaruhi sikap dan perilakunya, sehingga lebih berhati-hati dalam melakukan kegiatan berenang di Pantai Barat Pangandaran. Weiler dan Smith (2009) menemukan bahwa pengunjung menunjukkan luaran kognitif, afektif dan perilaku yang lebih baik dengan meningkatnya paparan terhadap media interpretasi. Selain itu, visualisasi mengenai bahaya arus rip juga perlu dilakukan untuk lebih memudahkan pengunjung memahami bahayanya. Yang (2016) menemukan bahwa visualisasi yang realistis dapat membantu masyarakat umum dan pembuat kebijakan memiliki pemahaman yang lebih baik mengenai bahaya pantai.

Manajemen untuk bahaya tsunami dan gempa dengan tingkat keparahan tinggi namun peluang rendah (jarang terjadi), sehingga resikonya sedang, dapat dilakukan dengan cara mengalihkan/mentransfer resiko. Pengelola dapat mengandalkan asuransi untuk mentransfer risiko kepada pihak ketiga. Investasi pada asuransi akan dilakukan oleh operator bisnis yang memahami potensi kerugian yang mungkin ditimbulkan oleh suatu bahaya, namun tidak memiliki sumberdaya fisik untuk mengatasi bahaya (Cioccio dan Michael, 2007). Cara lain yang dapat dilakukan yaitu dengan mengadopsi praktek keselamatan pengunjung yang baik dengan berbagai upaya pelatihan kepada petugas 
penyelamat pantai, melakukan simulasi kejadian, serta menerapkan prosedur kebijakan keselamatan (APEC 2004 diacu dalam UNEP 2008). Selain itu, perlu dikembangkan upaya pemulihan kawasan wisata pasca terjadinya tsunami, untuk menarik pengunjung datang kembali ke kawasan tersebut. Cioccio dan Michael (2007) menyarankan dilakukannya kegiatan pemasaran kolektif, segera setelah layanan infrastuktur penting di kawasan wisata telah diperbaiki, yang ditujukan untuk memperoleh kembali keyakinan pengunjung untuk kembali ke kawasan tersebut sehingga kunjungan ke kawasan dapat kembali seperti semula.

Resiko bahaya ombak tukik dengan resiko sedang dapat dikelola dengan cara mengurangi resiko. Pengurangan resiko dapat dilakukan dengan melibatkan masyarakat setempat, membangun perencanaan fisik kawasan, serta pengembangan zonasi pada lokasi pantai yang lebih aman dari ombak yang membahayakan.

Bahaya lainnya (monyet ekor panjang, ubur-ubur, ular laut, karang, dan bulu babi, serta ikan lepu ayam dan ikan lepu batu) dengan tingkat keparahan rendah dan frekuensi terjadinya rendah atau jarang, sehingga resikonya rendah/dapat ditoleransi dapat dikelola dengan menerima atau menolerir resiko yang ada. Hal ini dilakukan melalui pengawasan pengelola terhadap keselamatan pengunjung.

Tingkat resiko yang dapat ditoleransi seringkali dapat dipertahankan keberadaannya dalam wisata karena merupakan investasi pariwisata. Potensi bahaya dengan resiko rendah di Kawasan Wisata Pangandaran sebagian besar merupakan potensi bahaya dari faktor biologis, seperti ubur-ubur, ular laut, ikan lepu, bulu babi, dan monyet ekor panjang, yang seringkali menjadi daya tarik tersendiri bagi pengunjung. Manajemen bahayanya tentu tetap harus dilakukan pengelola untuk memastikan keselamatan dan kenyamanan pengunjung.

Peningkatan pemahaman pengunjung akan resiko dari setiap potensi bahaya diperlukan agar pengunjung dapat meningkatkan perannya dalam menjaga keselamatan pribadi dan/atau kelompoknya. Sebagian besar pengunjung wisata dipegunungan Alpen Austria memandang bahwa tidak adanya informasi mengenai resiko maka berarti bahwa di kawasan tersebut tidak ada resiko (Pröbstl-Haider et al., 2016). Ini menunjukkan pentingnya informasi mengenai resiko bahaya bagi pengunjung. Pemahaman akan resiko bahaya dan cara menangani resiko tersebut akan membantu pengunjung untuk lebih berhati-hati dalam melakukan aktivitas wisata, dan dapat melakukan pertolongan awal apabila terjadi kecelakaan. Informasi mengenai waktu dan tempat terjadinya bahaya juga perlu disampaikan kepada pengunjung. Bahkan meskipun kegiatan tersebut dilakukan, tidak berarti bahwa bahaya tersebut hilang sepenuhnya, namun merupakan tindakan untuk pencegahan dan pengurangan resiko. Berbagai kegiatan wisata justru lebih menarik bagi sebagian pengunjung karena bahaya yang dihadapinya. Jubenville et al. (1987) menyatakan bahwa pengelolaan keselamatan pengunjung yang berlebihan terkadang justru menghilangkan minat pengunjung terhadap suatu kawasan wisata.

\section{Kesimpulan}

Arus rip merupakan bahaya dengan resiko substansial yang seringkali terjadi di Pantai Barat Pangandaran. Pengelolaan bahaya arus rip dilakukan dengan mengindari bahaya ini, yaitu melalui penetapan zona berbahaya yang diiringi dengan peningkatan pengetahuan dan kemampuan pengunjung akan bahaya arus rip, mengenali kemunculannya, dan menyelamatkan diri dari arus rip. Selain itu, peningkatan pemahaman pengunjung terhadap setiap potensi bahaya yang dapat ditemui dalam kawasan, waktu, tempat dan resiko yang mungkin dialami, serta cara mengatasi bahaya tersebut menjadi penting untuk meningkatkan peran pengunjung dalam menjaga keselamatan dirinya dan/atau kelompoknya masing-masing. Berbagai media interpretasi dengan visualisasi yang realistis mengenai berbagai potensi bahaya dapat dimanfaatkan untuk keperluan tersebut.

\section{Daftar Pustaka}

[1] [BALAWISATA] Badan Penyelamat Wisata Tirta, 2011. Pendidikan dan Latihan Penyelamatan Wisata Tirta (Lifeguard). Balawista, Pangandaran

[2] [BMKG] Badan Meteorologi Klimatologi dan Geofisika, 2011. Data Gempa Bumi dan Tsunami Pangandaran. Stasiun Geofisika Kelas I Bandung, Bandung.

[3] [Disbudpar Kabupaten Ciamis] Dinas Kebudayaan dan Priwisata Kabupaten Ciamis, 2010. Pesona Budaya dan Pariwisata Kabupaten Ciamis. Disbudpar Kabupaten Ciamis, Ciamis.

[4] [DKP Kabupaten Ciamis] Dinas Kelautan dan Perikanan Kabupaten Ciamis, 2011. Laporan Statistik Perikanan Tangkap dan Budidaya Kabupaten Ciamis Tahun 2010. Pemerintah Kabupaten Ciamis, Ciamis.

[5] [UNEP] United Nation Environment Programme, 2008. Disaster Risk Management For Coastal Tourism Destinations Responding to Cilimate Change. A Practical Guide for Decisions Makers. UNEP, France.

[6] [UPTD] Obyek Wisata Ciamis] Unit Pelaksana Teknis Daerah Obyek Wisata Ciamis, 2011. Realisasi Pendapatan dan Masuknya Jenis Kendaraan di Tol Gate Wisata Pangandaran Tahun 2005-2011. Dinas Pariwisata Kebudayaan dan Pariwisata Kabupaten Ciamis, Pangandaran.

[7] Aziz, A., 1976. Apakah Ular Laut Berbahaya. Pewarta Oceana 2 (2), Pp. 15-20. [terhubung berkala] http://www.coremap.or.id/downloads/0645.pdf [15 November 2011].

[8] Cioccio, L., E.J. Michael, 2007. Hazard or disaster: Tourism management for the inevitable in Northeast Victoria. Tourism Management 28, pp. 1-11.

[9] Dhani, A.M., 2011. 10 Wisatawan Pangandaran Terseret Ombak. [terhubung berkala]. http//www.tribunnews.com [15 April 2011].

[10] Djunire, S., 2009. Kajian Bahaya dan Risiko Tsunami Berbasis Geomorfologi Untuk Menunjang Rencana Tata Ruang Kota Manokwari Provinsi Papua Barat. Tesis. Sekolah Pasca Sarjana Institut Pertanian Bogor, Bogor.

[11] Dobo, J., 2009. Tipologi Komunitas Lamun Kaitannya dengan Populasi Bulu Babi di Pulau Hatta, Kepulauan Banda, Maluku. Tesis. Sekolah Pascasarjana Institut Pertanian Bogor, Bogor.

[12] Gitrix, Praharani S., Sondakh, Tomo, 2005. Pengenalan Wawasan Maritim. Sekretariat Dewan Maritim Indonesia Departemen Kelautan dan Perikanan, Jakarta.

[13] Grift, J.V., 2006. What Is Natural Hazard. Terhubung berkala. http//www. natural hazard.org [15 April 2011].

[14] Gstaettner, A.M., K. Rodger, D. Lee, 2017. Visitor perspectives of risk management in a natural tourism setting: an application of the Theory of Planned Behavior. 
Journal of Outdoor Recreation and Tourism 19, pp. 110.

[15] Hendratmoko, Y., 2009. Studi Kohabitasi Monyet Ekor Panjang Dengan Lutung di Cagar Alam Pangandaran Jawa Barat. Tesis. Sekolah Pasca Sarjana Institut Pertanian Bogor, Bogor.

[16] Heriawan, Y., 1994. Komposisi, Distribusi, dan Kelimpahan UburUbur di Perairan Teluk Banten Bagian Barat, Kabupaten Serang, Propinsi Jawa Barat. Skripsi. Program Studi Manajemen Sumberdaya Perairan Fakultas Perikanan Institut Pertanian Bogor, Bogor.

[17] Howard, R.W., 2009. Risky business? Asking tourist what hazards they actually encountered in Thailand. Tourism Management 30, pp. 359-365.

[18] Hutabarat, S., S.M. Evans, 1984. Pengantar Oseanografi. Penerbit Universitas Indonesia (UI Press), Jakarta.

[19] Jubenville, A., B.W.Twight, R.H. Becker, 1987. Outdoor Recreation Management, Theory and Aplication. Venture Publishing, Inc., Oxford Circle.

[20] Kasim, M., 1999. Aktivitas Merumput dan Pertumbuhan Bulu Babi (Tripneustes gratilla Linnaeus) Pada Habitat Lamun di Perairan Bone-Bone Kabupaten Buton Propinsi Sulawesi Tenggara. Tesis. Program Pascasarjana Institut Pertanian Bogor, Bogor.

[21] Prasetiyo, A., 2006. Tingkat Kepuasan dan Sikap Pengunjung terhadap Atribut Objek Wisata "Taman Air" Tlatar, Kabupaten Boyolali, Jawa Tengah. Skripsi. Program Studi Manajemen Bisnis dan Ekonomi Perikanan Kelautan, Fakultas Perikanan dan Kelautan, Institut Pertanian Bogor, Bogor.

[22] Prihatiana, 2010. Deteksi Antibodi Rabies Pada Serum Monyet Ekor Panjang (Macaca fascicularis) Dari Lima Lokasi yang berbeda di Jawa Barat dan Sumatera Selatan [Skripsi]. Bogor: Fakultas Kedokteran Hewan. Institut Pertanian Bogor.

[23] Pröbstl-Haider, U., K. Dabrowska, W. Haider, 2016. Risk perception and preferences of mountain tourists in light of glacial retreat and permafrost degradation in the Austrian Alps. Journal of Outdoor Recreation and Tourism 13, pp. 66-78.

[24] Republika, 2007. 102 Pengunjung Pangandaran Terseret
Ombak. http//www. arsip.net/id/link.php [15 April 2011]

[25] Romimohtarto, K., Juwana, S., 2001. Biologi Laut: Ilmu Pengetahuan tentang Biota Laut. Penerbit Djambatan, Jakarta.

[26] Setyawan, W.B,, E. Kusmanto, S.M. Natsir, M. Hasanudin, 2010. Morfologi Pantai Pasir dan Pola Arus Dekat Pantai di Kawasan Wisata Pantai Teluk Parigi Pangandaran, Kabupaten Ciamis, Propinsi Jawa Barat. Jakarta: Pusat Penelitian Oseanografi. Lembaga Ilmu Pengetahuan Indonesia.

[27] Sugito, N.T., 2008. Tsunami. Jurusan Pendidikan Geografi. Fakultas Pendidikan Ilmu Pengetahuan Sosial. Universitas Indonesia.

[28] Surf Life Saving Australia, 2005. First Aid and Emergency care. Australia: Vaughn Curtis

[29] Tillah, M., 2006. Uji Pengaruh Toksisitas Venom Ubur-ubur Cyanea sp. Pada Suhu yang berbeda terhadap Daphinia sp. Skripsi. Bogor: Ilmu Teknologi Kelautan. Fakultas Perikanan. Institut Pertanian Bogor.

[30] Wahyuningsih, M., 2010. Racun Hewan Paling Mematikan di Laut Dalam. Terhubung berkala. http//www.scubadiver indonesia.com [29 Desember 2011].

[31] Weiler, B., Smith, L., 2009. Does more interpretation lead to greater outcomes? An assessment of the impacts of multiple layers of interpretation in a zoo context. Journal of Sustainable Tourism 17 (1), pp. 91-105.

[32] Widiastuty, H., D. Riana, P. Larasati, I.A. Putri, 2010. Status Populasi Monyet Ekor Panjang (Macaca fascicularis) di Cagar Alam Pananjung Pangandaran. Skripsi. Departemen Biologi Fakultas Matematika dan Ilmu Pengetahuan Alam Institut Pertanian Bogor, Bogor.

[33] Winni. 2011. Karakteristik Ekosistem Pesisir Untuk Kesesuaian Wisata Bahari di Pantai Pangandaran, Kabupaten Ciamis, Jawa Barat. Skripsi. Fakultas Perikanan dan Ilmu Kelautan Universitas Padjajaran, Bandung.

[34] Yang, B., 2016. GIS based 3-D landscape visualization for promoting citizen's awareness of coastal hazard scenarios in flood prone tourism towns. Applied Geography 76, pp. 85-97. 